\title{
APPENDIX: BASIS FOR AGE ASSIGNMENTS AT DEEP SEA DRILLING PROJECT SITES 502 AND 5031,2
}

\author{
Lloyd D. Keigwin, Jr., Woods Hole Oceanographic Institution, Woods Hole, Massachusetts
}

The purpose of this chapter is to summarize and compare faunal and floral datum levels from Sites 502 and 503 and to provide ages for these events based on magnetostratigraphy (Kent and Spariosu, this volume). The time scale used on Leg 68 (Fig. 1) is that of LaBrecque et al. (1977), updated with the revised decay constants of Mankinen and Dalrymple (1979). Reversals within Leg 68 holes are from Kent and Spariosu (this volume); all ages are interpolated between these levels, assuming constant accumulation rates of sediment.

Table 1 (in back pocket, this volume) presents the sample identification, depth range, and the calculated age range for Pliocene-Pleistocene datum levels of silicoflagellates, radiolarians, diatoms, planktonic foraminifers, and nannofossils and is based on chapters in the present volume and on information gathered at our postcruise meeting. No ages are provided below the level of the oldest reliably dated magnetic reversal. In most cases the ages of datum levels are tightly constrained by relatively close sampling coupled with the generally high accumulation rates at Sites 502 and 503. Careful examination of Table 1 reveals that even within the holes at one site the ages of datum levels may differ by 0.10 or $0.20 \mathrm{~m} . \mathrm{y}$. This must reflect uncertainties in species identification, flaws in the assumption of constant accumulation rates, the effects of bioturbation and gaps in core recovery, and in a general way may reflect the limits of biostratigraphic resolution.

Table 2 is an attempt to distill the information in Table 1 in order to arrive at an interpreted age for each datum level. The age estimates are subjectively determined, often by taking the midpoint of the age ranges presented in Table 1. In other cases age estimates are summarily eliminated, because, for example, of the uncertainty in choosing a depth downcore when only the core catcher sample was recovered. Unfortunately this problem was most severe at the Pliocene/Pleistocene

\footnotetext{
${ }^{1}$ Prell, W. L., Gardner, J. V., et al., Init. Repts. DSDP, Vol. 68: Washington (U.S. Govt, Printing Office).

2 Refer to Part II, Biostratigraphy, this volume, for appropriate taxonomy.
}

boundary at Site 502 , where there were large gaps in core recovery in two out of four holes.

Two nannofossil specialists examined Leg 68 material, and Tables 1 and 2 accordingly reveal a certain degree of disagreement between ranges of some species. In the case of the top of small Gephyrocapsa, this discrepancy is probably due to Rio's (this volume) failure to sample high enough at each site to record the true final appearance. Other differences (e.g., base $D$. assymmetricus and base $C$. rugosus) are unexplained at this time.

A preliminary comparison between datum level age assignments from Leg 68 material and those of previous workers reveals general agreement within about $0.2 \mathrm{~m}$.y. (Berggren, 1977; Burckle, 1977; Gartner, 1977; Theyer et al., 1978). This is close to the average spread of ages for each level given in Table 1, suggesting that the age estimates are reasonably accurate. A more rigorous comparison of this work with other data must await a new generation of studies using the revised geomagnetic polarity time scale. The worker wishing to use the age assignments in Table 2 is cautioned to return to the initial report of each biostratigrapher to evaluate the reliability of each datum level as well as to take into account the effects of changing sedimentation rates, gaps in core recovery, core disturbance and bioturbation, and the age ranges of each level in Table 1.

\section{REFERENCES}

Berggren, W. A., 1977. Late Neogene planktonic foraminiferal biostratigraphy of the Rio Grande Rise (South Atlantic). Mar. Micropaleont., 2:265-313.

Burckle, L. H., 1977. Pliocene and Pleistocene diatom datum levels from the equatorial Pacific. Quat. Res., 7:330-340.

Gartner, S., 1977. Calcareous nannofossil biostratigraphy and revised zonation of the Pleistocene. Mar. Micropaleont., 2:1-25.

LaBrecque, J. L., Kent, D. V., and Cande, S. C., 1977. Revised magnetic polarity time scale for Late Cretaceous and Cenozoic time. Geology, 5:330-335.

Mankinen, E. A., and Dalrymple, G. B., 1979. Revised geomagnetic polarity time scale for the interval $0-5$ m.y. B.P. J. Geophys. Res., 84(B2):615-626.

Theyer, F., Mato, C. Y., and Hammond, S. R., 1978. Paleomagnetic and geochronologic calibration of latest Oligocene to Pliocene radiolarian events, equatorial Pacific. Mar. Micropaleont., 3:377-395. 


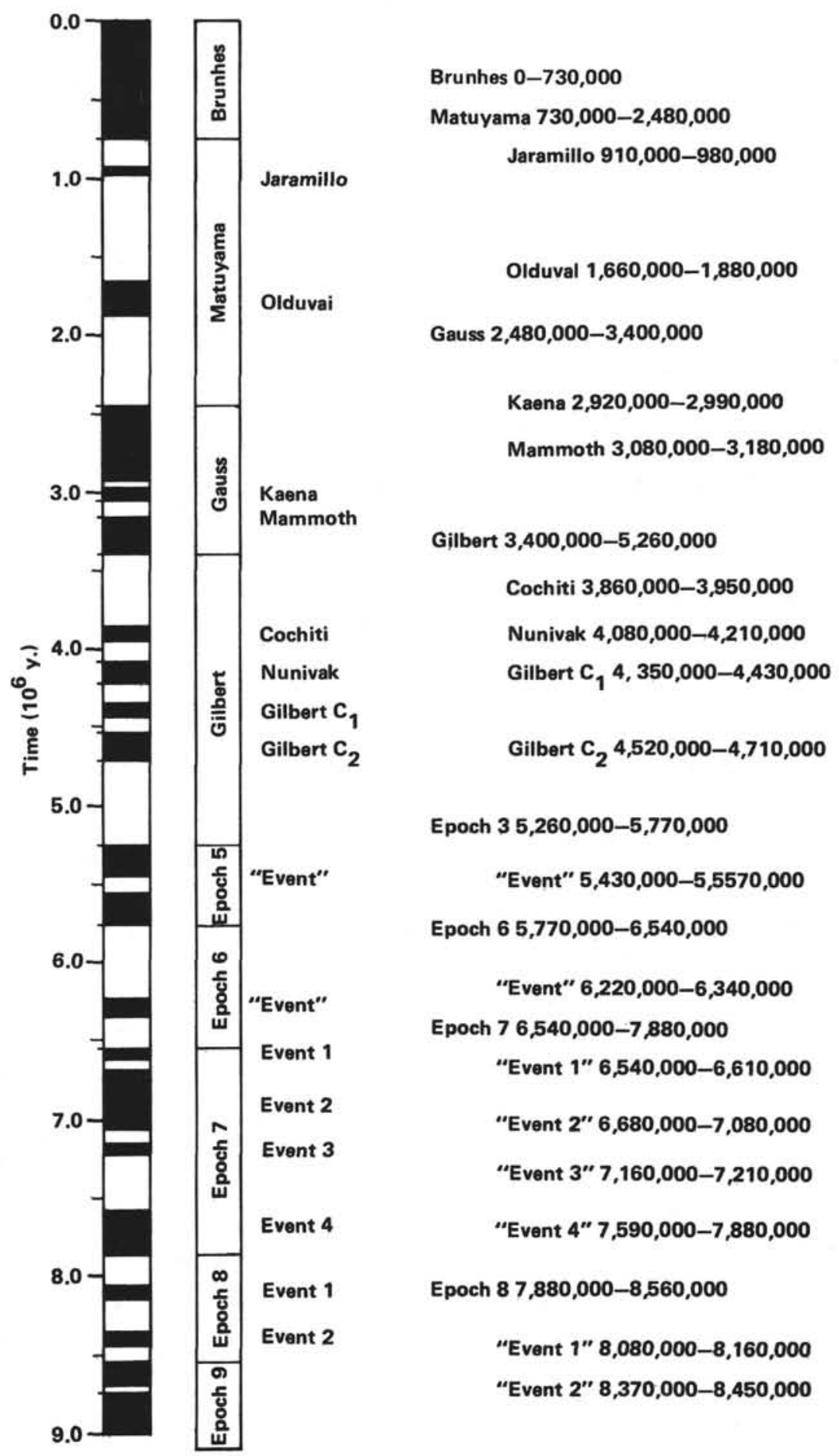

Figure 1. Paleomagnetic time scale used on Leg 68 (from LaBrecque et al., 1977) and modified according to Mankinen and Dalrymple (1979). 
Table 2. Estimated age of datum levels.

\begin{tabular}{|c|c|c|}
\hline Event & Datum Level & Age (m.y.) \\
\hline \multicolumn{3}{|c|}{ Radiolarians } \\
\hline 1 & Base $B$. invaginata & 0.10 \\
\hline 2 & Base C. tuberosa & 0.25 \\
\hline 3 & Top $A$. angelinum & 0.32 \\
\hline 4 & Top $A$. angulare & 0.90 \\
\hline 5 & Top $L$. neoheteroporos & 0.90 \\
\hline 6 & L. neoheteroporos $\rightarrow$ L. nigriniae & 1.00 \\
\hline 7 & $T$. vetulum $\rightarrow T$. trachelium & 1.10 \\
\hline 8 & Base $A$. angulare & 1.45 \\
\hline 9 & L. heteroporos $\rightarrow L$. & \\
\hline & neoheteroporos & 1.50 \\
\hline 10 & Base $T$. trachelium & 1.40 \\
\hline 11 & Top $P$. prismatium & 1.54 \\
\hline 12 & Top $S$. peregrina & 2.85 \\
\hline 13 & A. avita $\rightarrow D$. tetrathalamus & 3.00 \\
\hline 14 & Base L. heteroporos & 3.08 \\
\hline 15 & Top $L$. andax & 3.50 \\
\hline 16 & Top $P$. doliolum & 3.60 \\
\hline 17 & $S$. pentas $\rightarrow S$. tetras & 3.70 \\
\hline 18 & D. penultima $\rightarrow D$. avita & 3.70 \\
\hline 19 & Top $S$. ambus & $>3.82$ \\
\hline \multicolumn{3}{|c|}{ Diatoms } \\
\hline & Acme $R$. matuyamai & 0.90 \\
\hline & Top $M$. quadrangula & 0.63 \\
\hline & Top $N$. reinholdii & 0.80 \\
\hline & Base $M$. quadrangula & 1.15 \\
\hline & Top $R$. praebergonii & 1.50 \\
\hline & Base $P$, doliolus & 1.95 \\
\hline & Top $T$. convexa (group) & 2.33 \\
\hline & Top N. jouseae & 2.73 \\
\hline & Base $R$. praebergonii & 3.00 \\
\hline & Base $T$. convexa & 3.57 \\
\hline \multicolumn{3}{|c|}{ Foraminifers } \\
\hline & Base $G$. truncatulinoides & 1.95 \\
\hline & Base $P$. obliquiloculata (502) & 2.10 \\
\hline & Base $P$. obliquiloculata (503) & 2.45 \\
\hline & Base $N$. dutertrei & 2.50 \\
\hline & Top G. altispira & 2.90 \\
\hline & Top Sphaeroidinellopsis & 3.05 \\
\hline & Base $G$. miocenica & 3.10 \\
\hline & Base G. fistulosus & 3.10 \\
\hline & Base G. hirsuta & 3.40 \\
\hline & Base G. puncticulata & 3.32 \\
\hline & Top G. pertenuis (502) & 2.50 \\
\hline & Top G. pertenuis (503) & 3.20 \\
\hline & Base $G$. pertenuis & 3.40 \\
\hline & Base $G$. crassaformis (502) & 4.30 \\
\hline & Base G. crassaformis (503) & 3.60 \\
\hline & Base $G$. exilis & 3.70 \\
\hline & Top $P$. primalis ( 502 , middle-Plio.) & 3.40 \\
\hline & Base $S$. dehiscens (ss) & 3.50 \\
\hline & P. primalis coiling shift & 3.70 \\
\hline & Top G. margaritae & 3.60 \\
\hline & Top $N$. pachyderma (L-coiling, & \\
\hline & 502) & 4.00 \\
\hline & Top G. nepenthes & 4.10 \\
\hline & Top G. seigliei & 4.58 \\
\hline & Base $S$. dehiscens (f.i) & 4.67 \\
\hline & Base $P$ primalis $(502)$ & 4.30 \\
\hline \multicolumn{3}{|c|}{ Nannofossils } \\
\hline & Base $E$. huxleyi & 0.24 \\
\hline & Top $P$. lacunosa & 0.40 \\
\hline & Top small Gephyrocapsa & 0.90 (Blechschmidt); 3.35 (Rio) \\
\hline & Top $H$. sellii & 1.25 \\
\hline & Top C. macintyrei & 1.50 \\
\hline & Top D. brouweri & 1.90 \\
\hline & Top $D$. pentaradiatus & 2.30 \\
\hline & Top D. surculus & 2.60 \\
\hline & Top D. tamalis & 2.80 \\
\hline & Top $R$. pseudoumbilicus & 3.50 \\
\hline & Base $D$. assymmetricus & 4.40 (Blechschmidt); 3.28 (Rio) \\
\hline & Base C. rugosus & 4.40 (Blechschmidt); 3.54 (Rio) \\
\hline & Top C. acutus & 4.45 \\
\hline & Top D. quinqueramus & $>4.68$ \\
\hline
\end{tabular}

